\title{
СПЕЦИФИКА ФОРМИРОВАНИЯ ПРИГОРОДНЫХ ЗОН В КРАСНОДАРСКОМ КРАЕ
}

\author{
К. В. Пивень, А. А. Филобок \\ Кубанский государственный университет, Россия \\ Поступила в редакцию 15 февраля 2018 г.
}

\begin{abstract}
Аннотация: Пригородная зона городов-курортов Краснодарского края имеет важное значение для развития экономики региона. Именно она вносит большой вклад в обеспечение этой территории необходимыми средствами производства.
\end{abstract}

Ключевые слова: размещение населения, урбанизация, пригородная зона, город-курорт, урбанистический баланс.

Abstract: Suburban area of the resort cities in the Krasnodar Krai is important for the development of the region's economy. It makes a great contribution to the provision of this area with the necessary means of production.

Key words: population placement, urbanization, suburban area, resort city, urban balance.

Краснодарский край - основное ядро туристско-рекреационной зоны юга России. Более 12 миллионов туристов (включая, как местных, так и зарубежных) посещает Азово-Черноморское побережье ежегодно. Подавляющая часть прибывает в летние месяцы. Такой огромный поток отдыхающих в период «высокого сезона» сказывается на социально-экономической обстановке в регионе, в частности, обостряется проблема равномерного размещения населения и обеспечение его необходимыми условиями для комфортного проживания и отдыха. Именно обустройство пригородных зон способствует решению накопившихся проблем.

В стратегической перспективе санаторно-курортная составляющая рекреации может получить дополнительный импульс за счет реконструкции традиционных центров оздоровления и лечения и развития новых. Кроме того, территория Черноморского побережья России перспективна для формирования активного туризма - не реализован потенциал водно-парусного спорта, экологического туризма, познавательного и религиозно-этнического [2].

Определенные изменения функциональной структуры городов-курортов могут произойти после реализации новых проектов - особых экономических зон туристского типа (Крымский федеральный округ, Северо-Кавказский туристский клас-

() Пивень К.В., Филобок А.А., 2019 тер), игорных зон (Азов-Сити, Крымский федеральный округ, Сочи), а также сети туристско-рекреационных и автотуристских кластеров практически во всех субъектах региона.

Неотъемлемой частью крупных городов, стали пригородные зоны. Территории пригородных зон представляют собой исключительно интересный объект для исследования: именно здесь наиболее ярко проявляется проблема организации разумного баланса в части планировочных, коммуникационных, социальных, промышленных, экологических и иных предложений [5].

Пригородная зона - территория, расположенная по периметру границы города, предназначена для перспективного развития населенного пункта, размещения хозяйственной и социальной инфраструктуры.

Границы пригородной зоны определяются при разработке проекта генерального плана или проекта планировки и застройки населенного пункта.

В состав пригородных зон могут включаться земли, находящиеся за пределами черты городских поселений, составляющие с городом единую социальную, природную и хозяйственную территорию и не входящие в состав земель иных поселений.

В пригородных зонах выделяются территории сельскохозяйственного производства, зоны отдыха населения, резервные земли [3].

Город вместе с пригородной зоной превращается в «механизм» территориально-хозяйственной 
Границы пригородной зоны городов-курортов Краснодарского края (составлено автором)

\begin{tabular}{|c|c|c|}
\hline $\begin{array}{l}\text { № } \\
\Pi / \Pi \\
\end{array}$ & $\begin{array}{l}\text { Название города- } \\
\text { курорта }\end{array}$ & $\begin{array}{c}\text { Населенные пункты-границы между пригородной зоной и } \\
\text { сельской территорией }\end{array}$ \\
\hline 1. & Анапа & $\begin{array}{l}\text { Благовещенское, Малый Утриш, Суворов-Черкесский, } \\
\text { Виноградный, Гостагаевская }\end{array}$ \\
\hline 2. & Геленджик & Кабардинка, Джанхот, Прасковеевка \\
\hline 3. & Горячий Ключ & $\begin{array}{l}\text { Октябрьский, Пятигорская, Саратовская, Кутаисская, } \\
\text { Калужская }\end{array}$ \\
\hline 4. & Ейск & $\begin{array}{l}\text { Камышеватская, Должанская, Ясенская, Старощербиновская, } \\
\text { Ейское укрепление, Молчановка }\end{array}$ \\
\hline 5. & Новороссийск & $\begin{array}{l}\text { Дюрсо, Абрау-Дюрсо, Лесничество Абрау-Дюрсо, } \\
\text { Верхнебаканское, Нижнебаканское, Неберджаевская }\end{array}$ \\
\hline 6. & Приморско-Ахтарск & $\begin{array}{l}\text { Садки, Новонекрасовский, Ольгинская, Возрождение, } \\
\text { Бриньковская, Морозовский }\end{array}$ \\
\hline 7. & Сочи & Вишневка, Адлер, Красная Поляна, Эстосадок \\
\hline
\end{tabular}

интеграции, с сочетанием плюсов и минусов такого «симбиоза», с проявлением разнонаправленных процессов, где сочетаются инерционность и динамизм, концентрация и рассредоточение, специализация и интеграция, культурное обогащение и отсталость. Становление и дальнейшее развитие пригородных зон тесно связано с концепцией опорного каркаса территории, который служит инструментом познания реальной географии хозяйства и населения, раскрывает процессы и результаты территориально-хозяйственной интеграции. По мере роста города, увеличения его площади и разнообразия деятельности (экономической, социальной, культурной) его влияние на территорию усиливается. Используя ресурсы территории, город по достижении определенной границы переходит в постгородскую стадию развития [4].

Город-курорт - это специализированный комплекс, ведущая функция которого стимулирует появление дополняющих отраслей и видов деятельности. В городе-курорте наряду с основными функциями - лечение, отдых, туризм, получают развитие обслуживающие отрасли - научно-образовательная (курортология, подготовка медиков и экскурсоводов), транспортно-экскурсионная, стройспециндустрия, пищевая промышленность [7].

Такая специализация города в территориальном разделении труда определила высокую долю занятых в санаторно-курортном комплексе. Более $40 \%$ среднегодовой балансовой стоимости основных фондов приходится на предприятия курортно-рекреационного комплекса. Пищевая промышленность выступает как доминирующая отрасль по объему производимой продукции. Развитие курортно-туристского комплекса характеризуют такие показате- ли, как розничный товарооборот и оборот общественного питания. В городах-курортах они значительно превышают средние значения по региону [6].

Как правило, объем реализации платных услуг в расчете на душу населения в городах-курортах в 2 раза больше, чем в среднем по краю, при этом 40-50\% этой суммы составляют услуги, связанные с курортно-туристским комплексом. Сфера услуг - важнейшая статья дохода и занятости населения. Высокий уровень розничной торговли и сферы обслуживания населения - необходимое условие нормального функционирования курортно-туристского комплекса [1].

Пригородная зона курортов Краснодарского края тесно взаимосвязана с самим городом социально-экономическими, миграционными, культурными, историческими и многими другими связями. Принцип формирования пригородной зоны заключается в том, что в нее включаются земли, составляющие с центральным городом единую социальную, природную и хозяйственную территорию. Обязательным условием является наличие транспортного каркаса, обеспечивающего единство пространственно-временных связей между центром и отдельными частями пригородной зоны. Вот почему основное развитие территории идет именно вдоль транспортных путей. Пригородная зона обеспечивает комфортную среду для горожан, поддерживает экологическую безопасность, служит резервом для развития жилого фонда и промышленной инфраструктуры.

Качество жизни горожан в значительной степени зависит от состояния пригородной территории, где располагаются зеленые и рекреационные зоны, детские оздоровительные лагеря, дачные и 
коттеджные поселки, а для части горожан фактически являются основным местом жительства [8]. Также стоит отметить, что именно в пригородной зоне сосредоточены основные промышленные и сельскохозяйственные объекты, благодаря которым город получает большую часть финансовой прибыли.

Однако, понятие пригородной зоны курортов Кубани носит условный характер, так как отсутствует конкретное определение ее границ на картах землепользования и в научной литературе. Опираясь на нормативно-правовую базу Российской Федерации, взаиморасположение населенных пунктов на Кубани, мы попытались выделить пригородные зоны городов-курортов Краснодарского края с учетом того, что территория города и пригородной зоны должны находиться в тесной взаимосвязи, а также в социально-экономическом и географическом единстве.

Применив это условие, мы можем территориально и топографически выделить пригородную зону каждого города-курорта (таблица).

Пригород активно участвует в деятельности курорта, обеспечивая его необходимыми средствами производства для устойчивого развития региона (например, обеспечение рабочей силой различных отраслей промышленности и сельского хозяйства). Единая инфраструктура (транспортное сообщение, жилищно-коммунальный сектор, средства коммуникации и связи, учреждения образования, здравоохранения и культурного наследия) и история формирования данной территории также способствуют укреплению взаимосвязи между городской и пригородной зонами.

Пригород является важным «звеном» города. Динамичная туристско-рекреационная деятельность городов Азово-Черноморского побережья привела к бурному развитию всех сфер хозяйства в пригородной зоне, что непосредственно влияет на улучшение качества жизни как местных жителей, так и отдыхающих, а также способствует благоприятному имиджу территории, влияющему на экономическую и социальную стабильность региона.

\section{СПИСОК ЛИТЕРАТУРЫ}

1. Веселов И. С. Города Краснодарского края: основные этапы формирования и современное социально-экономическое положение : дис. ... канд. геогр. наук / И. С. Веселов. - Краснодар, 2007. - 150 с.

2. Воронина В. В. Города-курорты Черноморского побережья России: основные тенденции и направления развития в новых геоэкономических условиях /
В. В. Воронина, А. А. Филобок // Туризм и рекреация: фундаментальные и прикладные исследования : материалы X Международной научно-практической конференции. - Москва, 2015. - С. 301-308.

3. Земельное право / В. Х. Улюкаев [и др.]. - Москва : Юридическая фирма «Частное право», 2010. - 344 с.

4. Лаппо Г. М. География городов / Г. М. Лаппо. Москва : ВЛАДОС, 1997. - 480 с.

5. Пригородные зоны в территориальном планировании [Электронный ресурс] // Геоинформационный портал ГИС-Ассоциации. - URL : http://www.gisa.ru/ 65220.html (дата обращения 23.12.2017).

6. Филобок А. А. Города Азово-Черноморского побережья Краснодарского края: Экономико-географические аспекты развития: дис. ... канд. геогр. наук / А. А. Филобок. - Краснодар, 2004. - 227 с.

7. Чистяков В. И. Города-курорты Российского Причерноморья как специализированные комплексы / В. И. Чистяков, А. А. Филобок // Курортно-рекреационный комплекс в системе регионального развития : материалы II Региональной научно-практической конференции. 22 апреля 2005 г. - Краснодар, 2005. - С. 2.

8. Юрина Г. И. Роль крупного города в формировании пригородной зоны / Г. И. Юрина, Л. А. Юрин // Интерэкспо Гео-Сибирь-2015. - Новосибирск : Сибирский государственный университет геосистем и технологий, 2015. - Т. 3. - С. 229-232.

\section{REFERENCES}

1. Veselov I. S. Goroda Krasnodarskogo kraya: osnovnyye etapy formirovaniya i sovremennoye sotsial'noekonomicheskoye polozheniye : dis. ... kand. geogr. nauk / I. S. Veselov. - Krasnodar, 2007. - 150 s.

2. Voronina V. V. Goroda-kurorty CHernomorskogo poberezh'ya Rossii: osnovnyye tendentsii i napravleniya razvitiya $\mathrm{v}$ novykh geoekonomicheskikh usloviyakh / V. V. Voronina, A. A. Filobok // Turizm i rekreatsiya: fundamental'nyye i prikladnyye issledovaniya : materialy X Mezhdunarodnoy nauchno-prakticheskoy konferentsii. Moskva, 2015. - S. 301-308.

3. Zemel'noye pravo/ V. KH. Ulyukayev [i dr.]. - Moskva : YUridicheskaya firma «CHastnoye pravo», 2010. $344 \mathrm{~s}$.

4. Lappo G. M. Geografiya gorodov / G. M. Lappo. Moskva : VLADOS, 1997. - 480 s.

5. Prigorodnyye zony $\mathrm{v}$ territorial'nom planirovanii [Elektronnyy resurs] // Geoinformatsionnyy portal GISAssotsiatsii. - URL: http://www.gisa.ru/65220.html (data obrashcheniya 23.12.2017).

6. Filobok A. A. Goroda Azovo-CHernomorskogo poberezh'ya Krasnodarskogo kraya: Ekonomiko-geograficheskiye aspekty razvitiya: dis. ... kand. geogr. nauk / A. A. Filobok. - Krasnodar, 2004. - 227 s.

7. CHistyakov V. I. Goroda-kurorty Rossiyskogo Prichernomor'ya kak spetsializirovannyye kompleksy / V. I. CHistyakov, A. A. Filobok // Kurortno-rekreatsionnyy kompleks $\mathrm{v}$ sisteme regional'nogo razvitiya : materialy 
II Regional'noy nauchno-prakticheskoy konferentsii. 22 aprelya 2005 g. - Krasnodar, 2005. - S. 2.

8. YUrina G. I. Rol' krupnogo goroda v formirovanii prigorodnoy zony / G. I. YUrina, L. A. YUrin // Inter·ekspo

Пивень Ксения Владимировна

аспирант кафедры Экономической, социальной и политической географии ФГБОУ ВО Кубанский государственный университет, г. Краснодар, E-mail: piven kseniya@mail.ru

Филобок Анатолий Анатольевич

кандидат географических наук, доцент кафедры Экономической, социальной и политической географии ФГБОУ ВО Кубанский государственный университет, г. Краснодар, E-mail: econgeo@mail.ru
Geo-Sibir'-2015. - Novosibirsk : Sibirskiy gosudarstvennyy universitet geosistem i tekhnologiy, 2015. - T. 3. S. 229-232.

Piven' Kseniya Vladimirovna

Post-graduate student of the Department of economic, social and political geography, Kuban State University, Krasnodar, E-mail: piven_kseniya@mail.ru

Filobok Anatoliy Anatol'yevitch

Candidate of Geographical Sciences, Associate Professor of the Department of economic, social and political geography, Kuban State University, Krasnodar, E-mail: econgeo@mail.ru 